\title{
Analysis of migration trends and functions of areas inhabited by Roma: example of Međimurje county (Croatia) and the settlement of Kuršanec
}

\author{
Slaven Kliček ${ }^{\mathrm{A}^{*}}$, Jelena Lončar ${ }^{\mathrm{B}}$ \\ Received: April 20, 2016 | Revised: September 9, 2016 | Accepted: November 7, 2016
}

\begin{abstract}
Međimurje County stands out as a developed and densely populated county of Central Croatia. Demographic and socio-economic developmental trends of Međimurje indicate the referred-to status: age structure, birth rates, population activity rates and share of jobs are significantly higher than the Croatian average. At the same time, Međimurje is home to one of the largest Croatian Roma communities, ethnically homogeneous and spatially isolated, whose predominantly unfavourable geographical features make the opposite developmental pole of previously described developed areas inhabited by the majority population. Development indicators at county level have omitted concrete living conditions of Roma. They inhabit the rural periphery characterized by social and spatial segregation, unemployment and existence on the margins of society and settlements. This paper provides an analysis of housing, economic and social functions of areas inhabited by Roma, as well as migratory trends and main functional orientation of these areas in Međimurje County. In so, the settlement of Kuršanec will be emphasized as a representative example of areas inhabited by Roma in Međimurje County.
\end{abstract}

Keywords: Roma, Međimurje, Roma settlements, migrations, functional orientation

\section{Introduction}

Using population activity rates, aging index and employment and unemployment rates as relevant indicators, Živić and Pokos (2005) define Međimurje County as a socio-economically developed county. At the same time, it is home to the most numerous Roma community in Croatia. According to the official Census of Population, Households and Dwellings 2011, a total of 5,107 residents declared themselves as Roma people in Medimurje, comparing to the City of Zagreb which comes second after Međimurje with a population of 2,755 declared Roma. These data should be used carefully having in mind the difficulties of col- lecting statistical data about Roma population ${ }^{1}$ (Report on enforcement of Action plan for implementation of National strategy for Roma inclusion in period

\footnotetext{
1 The reasons for low credibility of official Censuses regarding data on Roma are seen in irregular registering of Roma residences, inconsistent acquiring of official data on Roma population, distrust of Roma people towards official enumerators and appearance of ethnomimicry among Roma. It is assumed that the total number of Roma in Međimurje is significantly higher than the information reported by the Croatian Bureau of Statistics. The research of the UNDP Croatia in 2013 shows that 5,145 Roma are reported living in 9 of 12 areas inhabited by Roma in Međimurje County that are analyzed in this paper (data for the other three areas is not available) (Šlezak, 2010), while the Action Plan for Roma Inclusion in Medimurje County 2013-2015 estimates that the number of Roma in Međimurje County is between 7,000 and 9,000.
}

\footnotetext{
A Assistant Expert for EU projects at Faculty of Electrical Engineering and Computing, University of Zagreb, Unska 3, 10000 Zagreb; slaven.klicek@gmail.com

B Department of geography, Science faculty, University of Zagreb, Marulićev trg 19/2, 10000 Zagreb, Hrvatska; jloncar@geog.pmf.hr

* Corresponding author: Slaven Kliček, e-mail: slaven.klicek@gmail.com
} 
2013-2015.) The Roma community is dispersed across Međimurje County, while on local level they tend to concentrate in settlements of rural peripheries, spatially isolated from areas where the majority population lives.

As space is divisible among many users, its use is decided by a large number of participants with different interests. This often leads or may lead to conflicts of interest. Spatial relations are changing under the influence of population change, increase of economic activities and other factors. Despite the longstanding application and a relatively high number of spatial plans for different areas in Međimurje County, they did not result in anticipated implementation of planned measures (Spatial Plan of Međimurje County, 2001). The stated is especially manifested in the areas inhabited by Roma, which are mostly illegally constructed, with property and legal issues unsolved. Legalization of these sites is proceeding slowly due to slow involvement of the Roma community in the process (Action Plan for Roma Inclusion in Međimurje County, 2013).

During the 1990s, authors have dealt with intercultural relations, education of Roma and tracing historical roots of Roma migrations to specific Croatian regions, such as Podravina and Međimurje. United Nations Development Programme Croatia (UNDP) conducted specific research in Croatian concerning Roma population, which was followed with the publishing of several publications (Roma and the displaced in Southeast Europe, Roma Inclusion Working Papers: Civil Society, civil society involvement and Social Inclusion of Roma, Roma Inclusion Working Papers: Integrated household surveys among Roma populations, The Right of Roma Children to Education). Drawing upon the stated, authors considered that spatial aspects of the Roma community, including topics of migration, isolation issues and functional analysis is not researched sufficiently in scientific literature and therefore will provide new insights in the research about Roma population.

This paper will analyse some characteristics of the Roma community, features of the area in which they live and selected demographic structures and processes in which Roma participate on the example of the settlement of Kuršanec. Based on presented findings, a contribution to further understanding of the complex interrelationship between Roma community and the specific rural environment of Medimurje County in which Roma live will be carried out, with the main objective of determining the functional focus of areas inhabited by Roma in the county.

\section{Theoretical framework and research methodology}

In recent years, different Croatian authors researched problems of Roma with the aim of obtaining data on demographic and socio-cultural features, spatial segregation issues, settlement characteristics of Roma, their position in society and their customs. This paper sets goal to make a functional analysis of areas inhabited by Roma in Međimurje County. The analysis is based on field research conducted by UNDP Croatia in June and July 2013 in the settlement of Kuršanec, in which one of the authors participated. Interviewers who conducted the research are known to the inhabitants of Kuršanec so the credibility of collected data is at high level, as opposed to other sources which often provide questionable results. The study was conducted as part of the UNDP project "Platform for Roma Inclusion in Medimurje County" (from January to the end of December 2013). Collected data was provided to the authors in order to write this article. The field research in Kuršanec listed a total of 197 Roma households and 1,134 inhabitants (Table 1). The questionnaire used in the research consisted of three parts

Table 1. General information on the Roma part of Kuršanec settlement

\begin{tabular}{|l|c|l|c|}
\hline \multicolumn{4}{|l|}{ General information on the Roma part of Kuršanec settlement } \\
\hline Number of households & 197 & Number of couples & 200 \\
\hline Population & 1,134 & Men & 579 \\
\hline Number of adults & 444 & Women & 555 \\
\hline Number of minors & 690 & Average age & 17,7 \\
\hline Religion & 426 & Marriage status & 57 \\
\hline Roman Catholic & 5 & Extramarital union & 314 \\
\hline Baptist & 12 & Widow / widower & 21 \\
\hline Undecided & 1 & Divorced & 4 \\
\hline Other & & Not in a relationship & 48 \\
\hline
\end{tabular}

Source: UNDP field survey, 2013 
by which data was collected regarding adults and minors, households and infrastructure, facilities, financial standard, social and security issues, work habits, demographic, economic and educational structures. In addition to the field survey, information was obtained by direct queries sent to municipal and county authorities, which pointed to other areas inhabited by Roma in Međimurje County. Gathered information pointed to 12 areas with a higher concentration of Roma (more than 30 people), which are spatially separated from parts of settlements where the majority population lives (although both areas belong to the same administrative units).

\section{Case study Kuršanec}

The administrative settlement Kuršanec consists of two spatially separated parts, in which Roma people live separately from the majority population (Šlezak, 2010). The information presented in this paper regarding Roma part of the settlement of Kuršanec will serve as a framework for better understanding the 12 areas of Međimurje County inhabited by Roma. Analysing Roma distribution on local level and according to the official Census 2011, there is a total of 18 administra- tive cities and municipalities with Roma population in Međimurje County. Considering previously described areas with higher concentration of Roma people, i.e. Roma settlements, they are found in 10 municipalities and administrative cities.

\section{Spatial structure and isolation of areas inhabited by Roma}

\section{Spatial characteristics of Roma rural settlements} From 2004 to the present day, Offices for Physical Planning of different counties in Croatia have identified 14 counties with areas inhabited by Roma, i.e. Roma settlements, which require spatial organization and infrastructural equipping (National Strategy for Roma Inclusion, 2012). In Međimurje County there are 12 areas where a majority of Roma people lives (Table 2 and Figure 1 ).

Međimurje's specific land relief determined the density and typology of settlements in Međimurje. Lower Međimurje has a population density greater than Upper Međimurje, where hill terrains dominate and cause a dispersed population distribution. Areas

Table 2. Roma people in the ethnic structure of Međimurje County

\begin{tabular}{|c|c|c|c|c|}
\hline $\begin{array}{l}\text { Administrative unit } \\
\text { (city / municipality) }\end{array}$ & Number of Roma & $\%$ & $\begin{array}{l}\text { Area inhabited by } \\
\text { Roma }\end{array}$ & $\begin{array}{l}\text { Estimated number of } \\
\text { Roma }\end{array}$ \\
\hline Čakovec & 1039 & 3,83 & Kuršanec & $1134(2013)$ \\
\hline \multirow[t]{2}{*}{ Mursko Središće } & 285 & 4,52 & Hlapičina & $*$ \\
\hline & & & Sitnice & $*$ \\
\hline Belica & 1 & 0,03 & I & I \\
\hline Domašinec & 100 & 4,44 & Kvitrovec & $110(2011)$ \\
\hline Donja Dubrava & 7 & 0,36 & 1 & 1 \\
\hline Donji Kraljevec & 18 & 0,39 & l & I \\
\hline Donji Vidovec & 32 & 2,29 & I & I \\
\hline Goričan & 42 & 1,49 & Goričan & $42(2011)$ \\
\hline Gornji Mihaljevec & 1 & 0,05 & I & I \\
\hline Kotoriba & 320 & 9,93 & Kotoriba & 320 (2011) \\
\hline Mala Subotica & 694 & 12,73 & Piškorovec & $681(2011)$ \\
\hline \multirow[t]{2}{*}{ Nedelišće } & 1239 & 10,35 & Parag & 1187 (2011) \\
\hline & & & Gornji Kuršanec & $*$ \\
\hline Orehovica & 491 & 18,29 & Orehovica & 624 (2011) \\
\hline Podturen & 224 & 5,78 & Lončarevo & $224(2011)$ \\
\hline Pribislavec & 608 & 19,39 & Pribislavec & $800(2011)$ \\
\hline Selnica & 1 & 0,03 & / & / \\
\hline Štrigova & 3 & 0,11 & I & I \\
\hline Vratišinec & 2 & 0,1 & 1 & 1 \\
\hline Međimurje County & 5107 & 4,49 & 12 & $5145^{*}$ \\
\hline
\end{tabular}

Source: Atlas of Roma settlements in Međimurje County (www.hr.undp.org), Census of Population, Households and Dwellings 2011, data obtained from local administrative and other institutions

* For certain areas inhabited by Roma data on number of residents was not available. 


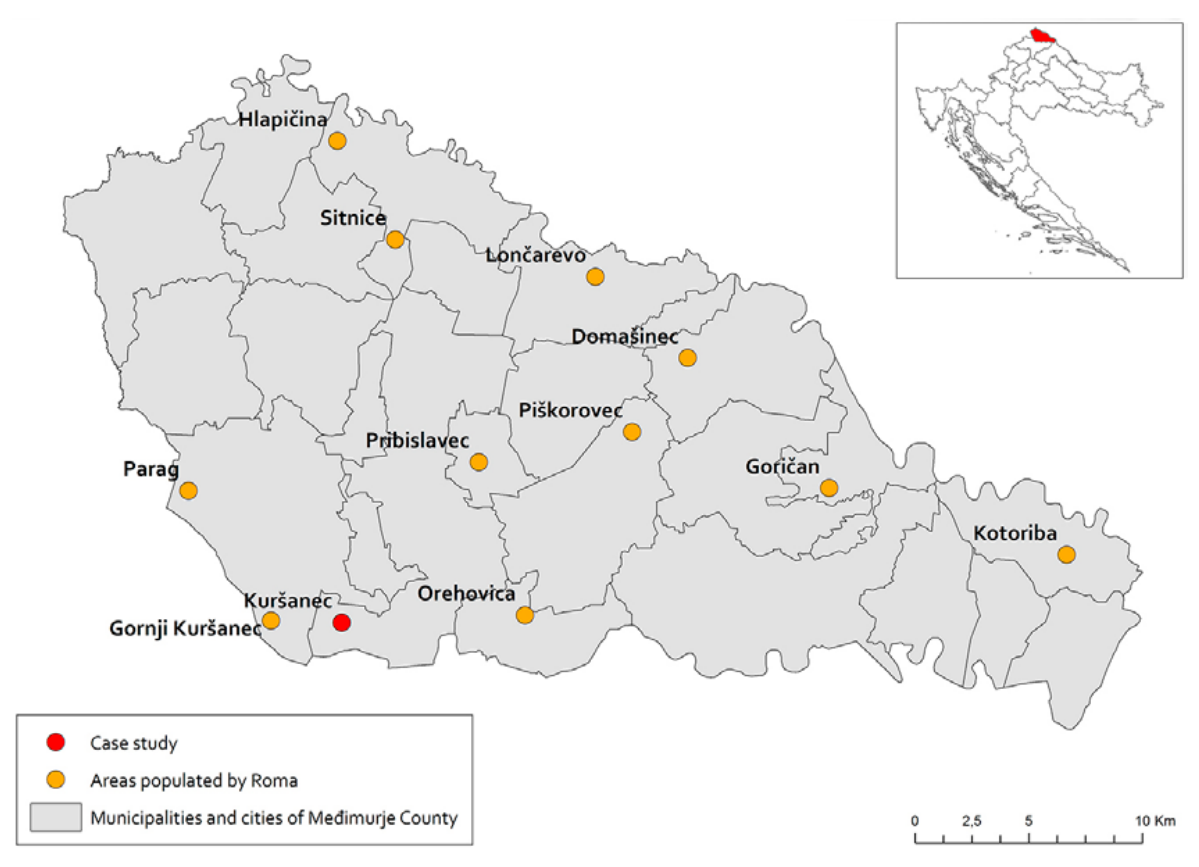

Figure 1. Areas inhabited by Roma in Međimurje County

inhabited by Roma in Međimurje County are spatially separated from parts of settlements where the majority population lives (Figure 2 and 3 ), although they belong to the same administrative units. Certain areas inhabited by Roma function as classic ghettos (Šlezak, Šakaja 2012; Šlezak, 2010) and generally have no utility infrastructure. Action Plan for Roma Inclusion in Međimurje County (2013) defines following areas of significant concentration of Roma population:

- isolated Roma settlements;

- Roma settlements as fragments of rural settlements;

- small group of individual houses built within rural settlements.

Some of these settlements originated from immigration of young families into separate housing units and by establishing independent households. There-

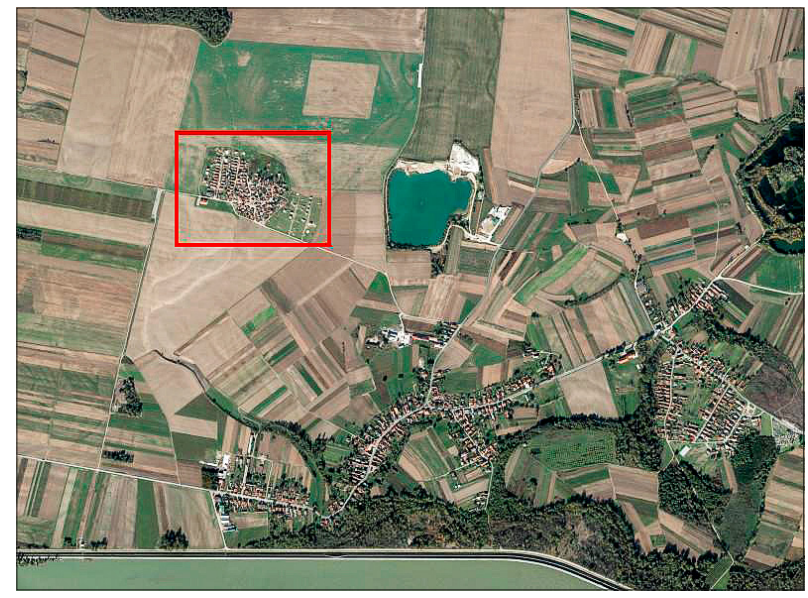

Figure 2. Example of spatial segregation of Kuršanec fore we can say that the spatial aspect is very important in the marginalization of Roma (Šućur, 2000). Cases of establishing households by partitioning previous ones usually do not appear, which is also an indicator of the financial situation and living standard of Roma people who rarely have a legacy to inherit and share among family members (First-Dilić, 1985).

According to the survey of Roma in Prekmurje in Slovenia, Josipovic and Repolusk (2003) defined closed, i.e. hidden Roma settlements, where Roma live in remote locations, far away from settlements of the majority population, next to forest or river areas. This classification of settlements can be applied to Međimurje as well, due to their similar pattern of distribution in rural areas. These areas inhabited by Roma in Međimurje are result of individual, substandard construction of housing units, using available materials with limited access to the infrastructure network.

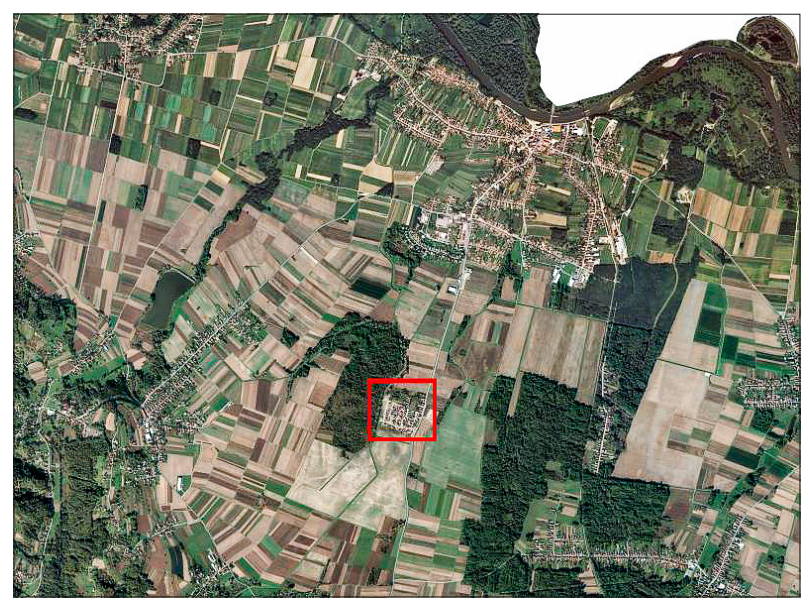

Figure 3. Example of spatial segregation of Sitnice 
The phenomenon of Roma settlements, i.e. specific areas inhabited by the Roma, is a sign of spatial segregation of a significant part of the Roma minority. Some of these settlements are completely polarized by ethnicity of its inhabitants. According to Šlezak (2009), absolute distances and physical barriers, such as forest areas, channels and/or railways, exist between settlement parts inhabited by Croat and Roma residents and thus define spatial segregation. In addition to high housing densities, inadequate planning and sometimes temporary features of areas inhabited by the Roma, many of these areas are not integrated in local spatial plans or they are built in areas not designed for housing. The Roma community cannot solve these problems alone, as they do not have sufficient institutional capacity in terms of acting in local government (Štambuk, 2000).

The main problem is that areas inhabited by Roma are built illegally on lots owned by the state, municipality, city and/or private parties, which complicates legislative issues for further construction or improve- ment. Only parts of areas inhabited by Roma are built on regulated building plots. In this way, future legalization efforts are threatened as unplanned construction is widely represented.

According to the analysis of building areas in Međimurje County, the part of Kuršanec inhabited by Roma is the only Roma settlement included in the Spatial Plan of Međimurje County. The situation in other areas is much more complex; land is owned by the state, municipality, city and/or private parties and the level of legalization is different from settlement to settlement (Table 3). In any case, it is necessary to determine concrete features of Roma settlements, their surface, legalization status and size, in order to plan current and future needs in new construction and development. Detailed spatial plans have been carried out and accepted for 8 isolated areas inhabited by Roma in Međimurje County, while other settlements have been included in spatial planning documents on municipal and city level (Action Plan for Roma Inclusion in Međimurje County, 2013).

Table 3. Property issues and construction data of areas inhabited by Roma

\begin{tabular}{|c|c|c|c|c|}
\hline $\begin{array}{l}\text { Areas inhabited } \\
\text { by Roma }\end{array}$ & Land ownership & Legalization & $\begin{array}{l}\text { Housing units size } \\
\qquad\left(\mathrm{m}^{2}\right)\end{array}$ & Construction material \\
\hline Kuršanec & $\begin{array}{l}\text { State and city owned (City } \\
\text { of Čakovec) }\end{array}$ & $\begin{array}{l}\text { Most of housing units } \\
\text { currently undergoing } \\
\text { legalization }(92 \%) \text {. }\end{array}$ & $40,77 \mathrm{~m}^{2}$ (average) & $\begin{array}{l}\text { Brick }(95 \%) \text {, concrete, tile, } \\
\text { cement material }\end{array}$ \\
\hline Parag & $\begin{array}{l}\text { Private ownership of } \\
\text { residents }\end{array}$ & $\begin{array}{l}61 \text { of } 226 \text { housing units } \\
\text { legalized. }\end{array}$ & $16-90 m^{2}$ & $\begin{array}{l}\text { Brick, concrete, tile, } \\
\text { cement material }\end{array}$ \\
\hline $\begin{array}{l}\text { Gornji } \\
\text { Kuršanec }\end{array}$ & $\begin{array}{l}\text { Private ownership of } \\
\text { residents }\end{array}$ & 16 illegal housing units. & $16-90 m^{2}$ & $\begin{array}{l}\text { Brick, concrete, tile, } \\
\text { cement material }\end{array}$ \\
\hline Pribislavec & $\begin{array}{l}\text { Private and (mostly) } \\
\text { municipal ownership } \\
\text { (Municipality Pribislavec) }\end{array}$ & $\begin{array}{l}80 \% \text { undergoing } \\
\text { legalization. } 20 \% \text { of illegal } \\
\text { housing units, not included } \\
\text { in detailed spatial plans. }\end{array}$ & $50-200 m^{2}$ & Concrete blocks, tile \\
\hline Orehovica & $\begin{array}{l}\text { Private ownership of } \\
\text { residents }\end{array}$ & $\begin{array}{l}103 \text { housing units legalized, } \\
24 \text { housing units undergoing } \\
\text { legalization. }\end{array}$ & l & $\begin{array}{l}\text { Tile, cement material. Few } \\
\text { older housing units built } \\
\text { from brushwood and clay }\end{array}$ \\
\hline Piškorovec & $\begin{array}{l}\text { Municipal ownership (Mala } \\
\text { Subotica) }\end{array}$ & Illegal objects. & $20-100 m^{2}$ & Brick, tile \\
\hline Kotoriba & $\begin{array}{l}\text { Municipal, state and private } \\
\text { ownership (Municipality } \\
\text { Kotoriba) }\end{array}$ & Illegal objects. & $50 \mathrm{~m}^{2}$ & Brick, tile \\
\hline Sitnice & $\begin{array}{l}\text { City ownership (Mursko } \\
\text { Središće) }\end{array}$ & $\begin{array}{l}\text { Legalization process under } \\
\text { way. }\end{array}$ & $70 \mathrm{~m}^{2}$ ( average ) & Brick, tile \\
\hline Hlapičina & I & I & I & I \\
\hline $\begin{array}{l}\text { Lončarevo } \\
\text { naselje }\end{array}$ & $\begin{array}{l}\text { Private and municipal } \\
\text { ownership (Municipality } \\
\text { Podturen) }\end{array}$ & $\begin{array}{l}\text { Part of housing units } \\
\text { undergoing legalization. }\end{array}$ & $40-80 m^{2}$ & Brick, tile, concrete \\
\hline Goričan & I & Illegal objects. & I & Concrete \\
\hline Domašinec & $\begin{array}{l}\text { Municipal and state } \\
\text { ownership (Municipality } \\
\text { Domašinec) }\end{array}$ & $\begin{array}{l}\text { Part of housing units } \\
\text { undergoing legalization. }\end{array}$ & $30-100 m^{2}$ & Brick, tile \\
\hline
\end{tabular}

Source: field survey conducted by UNDP in 2013, data obtained from local administrative and other institutions, Census of Population, Households and Dwellings 2011 
In order to effectively start solving issues of Roma settlements, Roma representatives stressed out priorities of increasing areas for future housing construction, providing financial assistance for housing and infrastructure and cleaning illegal waste disposal sites. Despite poor living conditions of these settlements, Roma people are not inclined to moving into neighbourhoods where mostly Croats live (Action Plan for Roma Inclusion in Međimurje, 2013.

\section{Economic structure of areas inhabited by Roma}

Roma people secure basic necessities and resources in different ways, but their professions, where employment exists, are mostly low-status. They mostly do occasional work in construction industry, agriculture or collect recyclable materials, which is today becoming more limited because of strict regulations on waste disposal and classification (Šućur, 2000). Roma people mostly choose economic activities in which a large number of family members can be included, ranging from the youngest to the oldest (Štambuk, 2005).

Considering the part of Kuršanec inhabited with Roma residents, the economic function is virtually non-existent (Table 4), taking into account that of 444 adults only 6 persons perform a full-time job. Only 15 Roma are occasionally employed (with or without a contract), while the rest of 419 people are unemployed, i.e. $94.37 \%$ of adult residents in the Roma part of Kuršanec. A great share of $75 \%$ of the adult population is receiving social assistance. The percentage of residents who receive child benefits is very high as well $(66 \%)$, which is not surprising considering the number of children. Also, more than half of the population (nearly $56 \%$ ) has never actively sought employment. The explanation for this is seen in low education levels of Roma and inadequate job qualifications, but also discrimination and prejudice which Roma often face when seeking employment. When asked about skills that can help in employment, Roma state babysitting (33.6\%), cooking and baking (24.6\%) and construction work $(37.8 \%)$ as most helpful. To avoid long-term unemployment of Roma, it is necessary to develop measures through a system of informal education which would limit their excessive reliance on social assistance. This could be achieved by co-financing their education and would result in a better quality of life (Development strategy of Međimurje County, 2011-2013).

\section{Communal infrastructure and utilities}

Transport and communal infrastructure are of great importance in shaping the quality of life and have a crucial role in economic development. Therefore, improving the standard of communal infrastructure is necessary for further development of areas inhabited
Table 4. Economic characteristics of Roma in Kuršanec

\begin{tabular}{|c|c|c|}
\hline Status & Abs. & Rel. \\
\hline Employed in Croatia & 6 & 1,35 \\
\hline Employed abroad & 0 & 0 \\
\hline $\begin{array}{l}\text { Temporarily employed in Croatia } \\
\text { (with contract) }\end{array}$ & 7 & 1,58 \\
\hline $\begin{array}{l}\text { Temporarily employed in Croatia } \\
\text { (without contract) }\end{array}$ & 0 & 0 \\
\hline $\begin{array}{l}\text { Periodically employed in Croatia } \\
\text { (without contract) }\end{array}$ & 8 & 1,8 \\
\hline $\begin{array}{l}\text { Periodically employed abroad } \\
\text { (without contract) }\end{array}$ & 0 & 0 \\
\hline Unemployed & 419 & 94,37 \\
\hline Receiving unemployment benefits & 4 & 0,9 \\
\hline Receiving social welfare & 333 & 75 \\
\hline Receiving childbirth benefits & 54 & 12,16 \\
\hline Receiving child benefits & 292 & 65,77 \\
\hline Self-employed: registered firm or craft & 2 & 0,45 \\
\hline Self-employed: unregistered firm or craft & 0 & 0 \\
\hline Partner in a firm & 0 & 0 \\
\hline Old-age pension & 6 & 1,35 \\
\hline Disability pension & 6 & 1,35 \\
\hline Taking care of households free of charge & 7 & 1,58 \\
\hline Student & 0 & 0 \\
\hline Receiving studentship & 0 & 0 \\
\hline Attending job training & 0 & 0 \\
\hline Other reasons for not working & 0 & 0 \\
\hline Receiving alimony & 0 & 0 \\
\hline $\begin{array}{l}\text { Financial support from friends or } \\
\text { relatives from Croatia }\end{array}$ & 1 & 0,23 \\
\hline $\begin{array}{l}\text { Financial support from friends or } \\
\text { relatives from abroad }\end{array}$ & 0 & 0 \\
\hline $\begin{array}{l}\text { Financial support from Church and } \\
\text { charity }\end{array}$ & 0 & 0 \\
\hline
\end{tabular}

Source: UNDP, field survey 2013

by Roma as places of residence and work. In some areas communal infrastructure was built with EU co-financing, but support and funding is needed for further improvement. Current infrastructural features of areas inhabited by Roma are shown in Table 5 .

Beside electric outlets, households do not have basic utilities such as sewage system, gas and water supply (only a minority of households has water outlets), thus access to hot water is not secured either. The gravity of the situation is evident in information regarding sanitary facilities; $56.9 \%$ of Roma households in Kuršanec have toilets outside housing units and another $22.3 \%$ of households share external toilets with neighbours. Waste is collected once a week, but the problem of waste disposal sites remains. The situation is better when considering access to electric- 
Table 5. Selected infrastructure indicators in 12 areas inhabited by Roma in Međimurje County

\begin{tabular}{|c|c|c|c|c|c|c|c|c|c|}
\hline Area & $\begin{array}{l}\text { Electrical } \\
\text { energy }\end{array}$ & $\begin{array}{l}\text { Water } \\
\text { supply }\end{array}$ & Sewerage & $\begin{array}{c}\text { Gas } \\
\text { access }\end{array}$ & $\begin{array}{l}\text { Street- } \\
\text { light }\end{array}$ & $\begin{array}{c}\text { Telephone } \\
\text { outlet }\end{array}$ & $\begin{array}{l}\text { Organized } \\
\text { waste } \\
\text { disposal }\end{array}$ & $\begin{array}{l}\text { Road } \\
\text { access }\end{array}$ & $\begin{array}{c}\text { Roads } \\
\text { inside of } \\
\text { settlement }\end{array}$ \\
\hline Kuršanec & $\checkmark$ & $\begin{array}{c}\checkmark(25 \\
\text { outlets) }\end{array}$ & $x$ & $x$ & $\checkmark$ & $\checkmark$ & $\begin{array}{l}\checkmark \text { (4 times } \\
\text { a month) }\end{array}$ & Asphalt & Asphalt \\
\hline Parag & $\checkmark$ & $\begin{array}{c}\checkmark(50 \\
\text { outlets) }\end{array}$ & $x$ & $x$ & $\checkmark$ & - & $\begin{array}{l}\checkmark \text { (not } \\
\text { used) }\end{array}$ & Asphalt & Asphalt \\
\hline $\begin{array}{l}\text { Gornji } \\
\text { Kuršanec }\end{array}$ & $\checkmark$ & $x$ & $x$ & $x$ & $\checkmark$ & - & $\checkmark$ & Macadam & Macadam \\
\hline Pribislavec & $\checkmark$ & $\begin{array}{c}\checkmark(23 \\
\text { outlets) }\end{array}$ & $\begin{array}{c}\text { x (part of } \\
\text { settlement) }\end{array}$ & $x$ & $\checkmark$ & $\checkmark$ & $\checkmark$ & Asphalt & $\begin{array}{l}\text { Asphalt, } \\
\text { pedestrian- } \\
\text { bike path }\end{array}$ \\
\hline Orehovica & $\checkmark$ & $\begin{array}{c}\checkmark \quad(5 \\
\text { outlets) }\end{array}$ & - & - & $\checkmark$ & - & $\begin{array}{l}\checkmark \text { (2 times } \\
\text { a month) }\end{array}$ & Asphalt & Asphalt \\
\hline Piškorovec & $\checkmark$ & $\checkmark$ & $x$ & $x$ & $\checkmark$ & $\checkmark$ & $x$ & Asphalt & $\begin{array}{l}\text { Asphalt, } \\
\text { pedestrian } \\
\text { path }\end{array}$ \\
\hline Kotoriba & $\checkmark$ & $\begin{array}{c}\checkmark(12 \\
\text { outlets) }\end{array}$ & $x$ & $x$ & $\checkmark$ & - & $x$ & Asphalt & Asphalt \\
\hline Sitnice & $\checkmark$ & $\begin{array}{c}\checkmark(42 \\
\text { outlets) }\end{array}$ & $x$ & $x$ & $\checkmark$ & - & $\checkmark$ & Asphalt & Asphalt \\
\hline Hlapičina & - & - & - & - & - & - & - & - & - \\
\hline Lončarevo & $\checkmark$ & $\begin{array}{c}\checkmark(11 \\
\text { outlets) }\end{array}$ & $\begin{array}{c}\boldsymbol{x} \text { (under } \\
\text { construction) }\end{array}$ & $x$ & $\checkmark$ & - & $\checkmark$ & - & - \\
\hline Goričan & $\checkmark$ & $\begin{array}{c}\checkmark(5 \\
\text { outlets) }\end{array}$ & - & - & - & - & $\checkmark$ & - & - \\
\hline Domašinec & $\checkmark$ & $x$ (well) & $x$ & $x$ & $\checkmark$ & - & $\checkmark$ & Macadam & Macadam \\
\hline
\end{tabular}

Source: UNDP, field survey 2013

ity grid, where over $90 \%$ of households have access, although illegal outlets prevail. The most common means of transportation is by bicycle. Domestic appliances have become widely used in households (such as washing machines, for example) as well as devices for leisure and entertainment (a majority of households have colour TV and about one-third has a radio). By using these utilities, the Roma population is adapting to contemporary housing standards, although still remaining in social ghettos (Hodžić, 1985). Thus other utilities, such as access to the Internet, computers and telephones, are underrepresented. Only 6 households have computers, while households with access to the Internet are not represented at all.

Regarding the housing standard (Table 6), most of the housing units were built in an unplanned manner by family members, using available materials and resulting with a modest quadrature. A large number of facilities are less than 10 square meters in size. More than three quarters of the settlement uses external toilets. The consequences are visible in the unattractive visual state of Kuršanec, marked by illegal construction and an extremely low living standard which supports the view that Roma live in conditions far worse than the majority population (Living condi- tions for the Roma, 2012). Other researched areas inhabited by Roma also share similar spatial and social characteristics.

Social factors as development indicators, which encompass living and work conditions, social, cultural and sport needs, health, education, services and especially housing, are not satisfactory in areas inhabited by Roma in Međimurje County. United Nations program on Housing defines appropriate housing as more than a roof over one's head. It includes space, physical access, appropriate insurance, structural stability and durability, adequate lighting, heating and ventilation, suitable basic infrastructure such as water supply, sanitary utilities, space for waste disposal and an adequate and accessible location concerning place of work and living. All of the stated should be available with affordable costs (National Strategy for Roma Inclusion, for the period 2013 to 2020). Most of it is non-existent in areas inhabited by Roma, although new construction or adaptions happened relatively recently (two thirds of housing objects was built or had adaptions after 1990) (Miletić, 2005).

Therefore authorities competent for matters of social welfare should have up-to-date registers of social and living conditions for Roma population. The 
Table 6. Selected infrastructural and housing indicators in Kuršanec, household level

\begin{tabular}{|l|c|l|c|}
\hline Housing & $\begin{array}{c}\text { Infividual (family } \\
\text { members), } 88,3 \%\end{array}$ & Sewerage & $0,0 \%$ \\
\hline Construction material & Brick, $98,5 \%$ & Drinking water from household (water supply) & $9,1 \%$ \\
\hline Average size & $40,77 \mathrm{~m}^{2}$ & Access to warm water & $9,6 \%$ \\
\hline Average room number & 1,57 & Gas & $1,0 \%$ \\
\hline Average number of glass-windows & 3,03 & Electricity & $92,9 \%$ \\
\hline \multirow{3}{*}{ Toilet location } & External (private) $56,9 \%$ & Telephone outlet & $18,8 \%$ \\
\cline { 2 - 4 } & $\begin{array}{c}\text { External (shared with } \\
\text { neighbours) } 22,3 \%\end{array}$ & Internet & $0,0 \%$ \\
\cline { 2 - 4 } & Internal (private) $9,1 \%$ & Cell phone & $50,8 \%$ \\
\hline Drinking water source & Well, hand pump, 88,8\% & Car & $17,3 \%$ \\
\hline \multirow{2}{*}{ Material used in cooking } & Wood 67,0\% & Colour TV & $89,9 \%$ \\
\cline { 2 - 4 } & Gas (tank) 47,2\% & Bed for every family member & $42,1 \%$ \\
\hline Material used for heating & Wood, 99\% & Computer & $3,0 \%$ \\
\hline
\end{tabular}

Source: UNDP, field survey 2013

fact is, however, that social and economic problems of the Roma minority are not solved successfully, due to measures implemented by competent authorities. Rather than implementing integrated social and economic incentives, these measures rely mostly on financial imbursements with no follow-up. A way to create new opportunities and integrate Roma in Medimurje is seen through the implementation of education programs, (re)qualification programs and targeted activities to reduce unemployment and social imbursement reliance. Therefore, it is necessary to solve infrastructure problems, adapt inadequate housing units and encourage housing integration of Roma families in municipalities and cities, but at the same time take care of the environment, in order to improve the quality of life in areas inhabited by Roma.

\section{Migratory characteristics of Roma people in Međimurje}

Considering migratory characteristics of Roma, it can be concluded that most of Roma population in Međimurje County is indigenous. According to Census 2001, $84 \%$ of Roma in Međimurje county lives in the same settlement since birth (Pokos, 2005), and the data are confirmed by UNDP's research in 2013. In the settlement of Kuršanec for example, 1,005 inhabitants or $88,62 \%$ lives in this settlement since birth, while there is only 100 newly settled persons (Table 7).

Analysis of migratory characteristics according to age groups indicated new understandings (Table 8). On the grounds of birthplace and year of immigration, migratory characteristics of Kuršanec inhabitants are determined. Of 444 adult inhabitants, 100 immigrated from other, mostly Roma settlements of Međimurje and neighbouring Varaždin Coun- ty. Altogether, $22 \%$ immigrated from other settlements. As expected, the largest mobility occurs in the young age-group. Thereby, $60 \%$ of all migrations into Kuršanec refer to the age-group of 15-19 years, while larger age-groups, i.e. Roma up to 19 years of age, cover more than $4 / 5$ of all immigrants. According to gender characteristics, a predominance of Roma women in immigration occurs, which is explained in the following text.

Table 7. Inhabitants of Kuršanec according to place of immigration

\begin{tabular}{|l|c|}
\hline Place of birth & $\begin{array}{c}\text { Number of immigrated } \\
\text { persons (18+) }\end{array}$ \\
\hline Pribislavec & 20 \\
\hline Trnovec & 20 \\
\hline Strmec* & 15 \\
\hline Orehovica & 8 \\
\hline Piškorovec & 8 \\
\hline Kotoriba & 4 \\
\hline Podturen & 4 \\
\hline Sitnice & 2 \\
\hline Varaždin* & 2 \\
\hline Goričan & 2 \\
\hline Gojanec* & 1 \\
\hline Totovec & 1 \\
\hline Domašinec & 1 \\
\hline Strahoninec & 1 \\
\hline Ludbreg* & 1 \\
\hline Other settlements & 10 \\
\hline Total & 100 \\
\hline Sourc:upP & \\
\hline
\end{tabular}

Source: UNDP, field survey 2013

* Varaždin County 


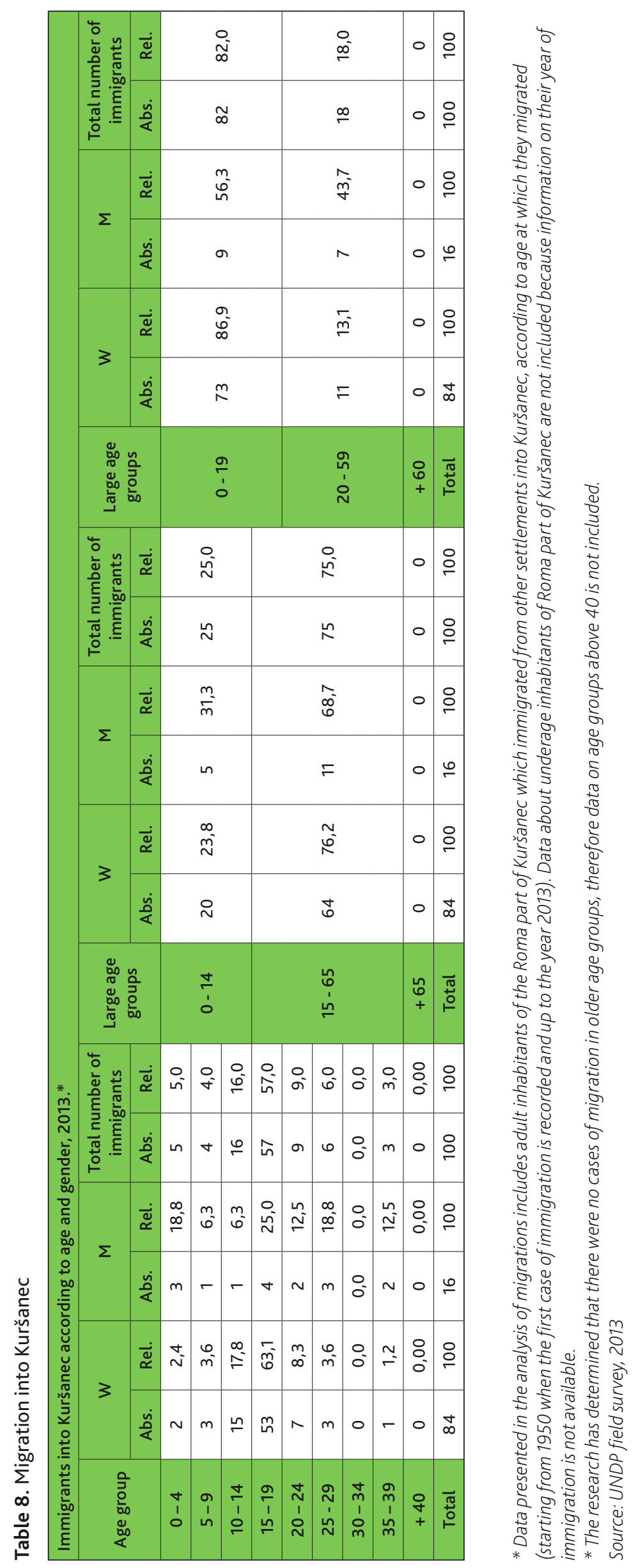




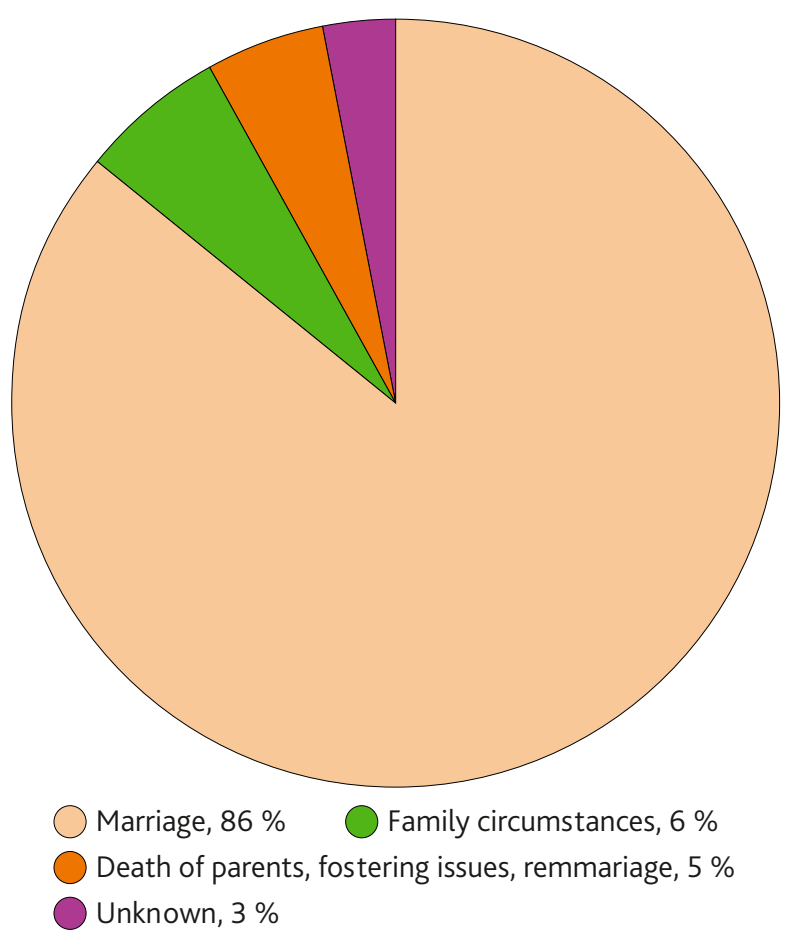

Figure 4. Reasons for migration to Kuršanec

Migration reasons explain the main motives for Roma to move into Kuršanec (Figure 4). Most of Roma's spatial mobility (90\%) is connected with matrimonial circumstances. Differences between Roma men and women occur at this point; of the total number of immigrants to Kuršanec, $83,5 \%$ are women who immigrate because of marriage reasons.

Further understanding of spatial mobility of Roma in Kuršanec can be explained by analysing family relations on household level. Only one household in Kuršanec stated that they do not have any relatives in
Table 9. Householdes in Kuršanec with relatives in other settlements

\begin{tabular}{|l|c|c|}
\hline Name of settlement & $\begin{array}{c}\text { Number of } \\
\text { households }\end{array}$ & $\begin{array}{c}\text { Share (\%) of } \\
\text { households }\end{array}$ \\
\hline Pribislavec & 70 & 35,53 \\
\hline Parag & 66 & 33,50 \\
\hline Strmec* & 45 & 22,84 \\
\hline Orehovica & 41 & 20,81 \\
\hline Kotoriba & 16 & 8,12 \\
\hline Piškorovec & 10 & 5,08 \\
\hline Gornji Kuršanec & 8 & 4,06 \\
\hline Sitnice & 4 & 2,03 \\
\hline Podturen & 3 & 1,52 \\
\hline Goričan & 2 & 1,02 \\
\hline Puščine & 2 & 1,02 \\
\hline Other settlements in Croatia & 29 & 20,87 \\
\hline Total & 296 & 156,4 \\
\hline
\end{tabular}

Source: UNDP, field survey 2013

* Varaždin County

the settlement, while the rest of 196 households noted they have (mostly) close family in the settlement. Most answers relate to brothers or sisters in the settlement (174 households), then parents (96), mothers in law and fathers in law (58) and children (54). A significant number of households noted they have relatives in nearby settlements of Međimurje county (70,56 \%) (Table 9) and abroad (17,26\%).

The presented data on migration characteristics of Roma point to the importance of traditional way of life and early matrimony as factors for better under-

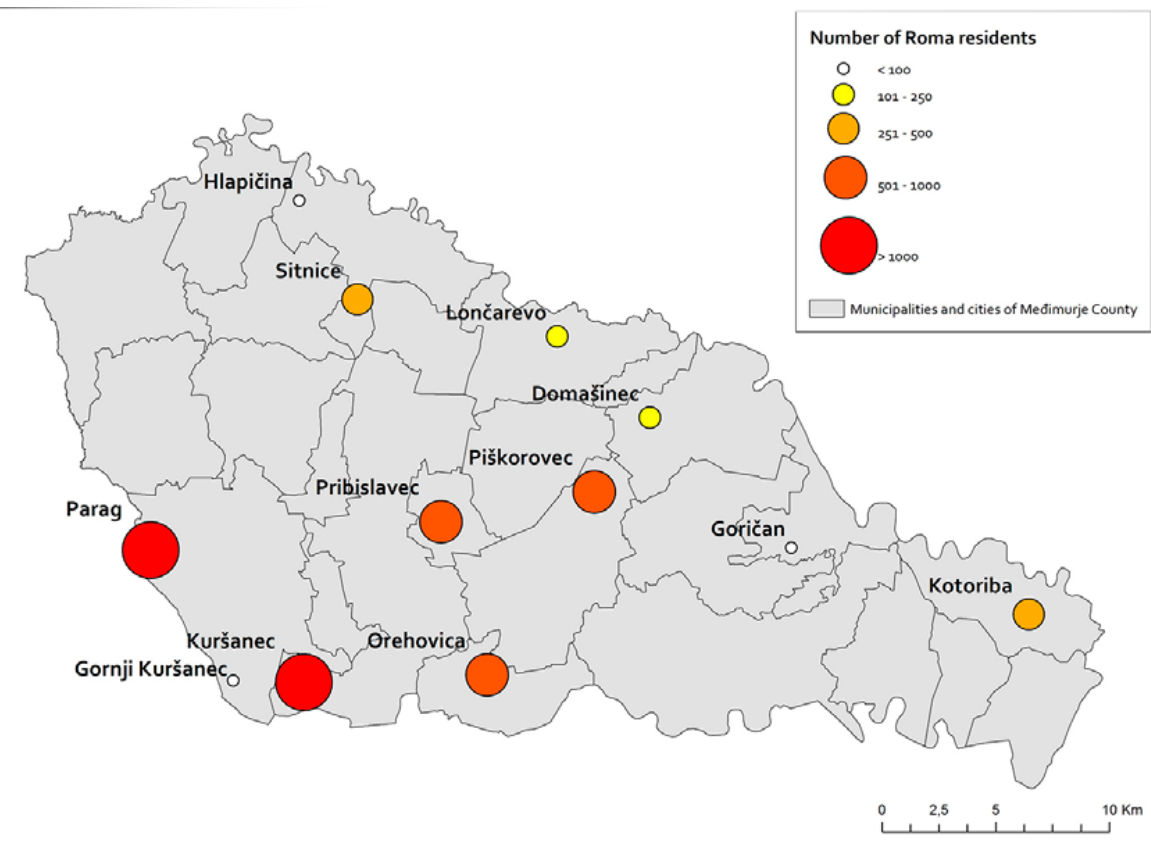

Figure 5. Number of Roma residents 
standing spatial mobility of underage Roma. Large number of the Kuršanec households with family ties in neighbouring areas inhabited by Roma confirm the link between the spatial mobility of Roma and traditional family values based on specific social organization of extended families and Roma family relations (Posavec, 200o). According to Hrvatić (2004) there are two different Roma statuses; the isolated one in the rural surroundings with preserved ethnical and cultural self-consciousness, and the other where Roma people live in a non-segregated way with the majority population and mostly in urban areas. The author also highlights Međimurje and 14 satellite Roma settlements of different sizes, connected with kin roles and family ties. The Roma society considers family as a basis of organization, which partly explains marginalization of Roma; a high degree of self-dependence of Roma families, existing also in the economic aspect (Štambuk, 2005), allows existence in spatially segregated areas. It is assumed that Roma people migrate between Roma settlements in family groups rather than individually (Štambuk, 2005). Economic migration does not occur, except in a minor number of cases, which implies lower work activity of Roma population, in spite of a favourable age structure. Main motives for migration, such as new work opportunities, possibilities to improve life standard and make higher earnings, which are common for the general population (Nejašmić, 2005), are less important in the Roma situation because of previously mentioned ways of making earnings and importance of traditional values.

\section{Functions of Roma settlements}

When analysing functions of Roma settlements, it is necessary to highlight that areas populated with Roma are not separated statistical settlements (except Parag and Piškorovec), although they are spatially and ethnically segregated. Therefore, taking into consideration their rural location in Međimurje's hinterland, it is logical to conclude that Roma people satisfy most of the needs outside settlements, as the settlements themselves lack basic facilities.

To better understand functional orientation of areas populated by Roma, data on the infrastructure is used. In Figure 6 we can analyse these functions, based on the research of Roma settlements in Prekmurje county, Slovenia (Zupančić, 2007), in which functions of living and housing, education, recreation, work and supply are used as representative indicators of processes and structures regarding Roma population in rural area. This paper adds health function to the analysis.

A monofunctional orientation of Roma areas is evident from the analysis, with housing functions as dominant in most $\operatorname{areas}^{2}$. Besides housing units, there are practically no other institutions or facilities with other purposes. But the quality of infrastructural facilities in settlements with several functions is questionable (cases of Orehovica and Piškorovec with existing recreational functions, i.e. unmaintained playgrounds). The monofunctional settlement structure brings us to a conclusion that Roma people satisfy their primary needs in settlements with the majority population, where most of supply, educational and health facilities are located. The stated is realized regarding supply and health needs, but from the previous analysis it is evident that economic and social interactions, as most relevant functions from a social and economy perspective, are practically non-existent. Minimum formal employment, low work activity, large shares of social incomes and low educational levels, leaves these areas in Međimurje's periphery. Exceptions are Roma employed in seasonal work (although a small number of cases), who often change places of residence, and Roma who collect and process secondary resources. Cases of theft in neighbouring agricultural areas occur in doing so (where Roma people are oftentimes considered as most likely suspects), as well as prohibited waste burning, which leads to conflicts with local inhabitants.

City of Čakovec, as a functional centre for a large part of Međimurje, does not influence Kuršanec, which is administratively part of the Čakovec area. The rest of the areas populated with Roma are located near smaller work centres, such as Kotoriba, Nedelišće and Mursko Središće. The functional orientation of these centres does not influence areas inhabited by Roma people, as is the case with Čakovec as well.

The conducted analysis carried out the fact that the health function in areas populated with Roma is nonexistent, as well as recreational ones. Sport facilities, sport halls, playgrounds and fields, as well as drugstores, are missing in these areas.

But the recreational function shows some specificity regarding the Roma population. Recreation is connected with Roma settlements; that is, different ways of socialization in Roma families and traditional values occur in link with recreation. It is this form of socialization that encourages cultural and language preservation, but at the same time reduces interaction between Roma people and the majority population, thus further playing a role in segregation and social misbalance. Although $90 \%$ of Kuršanec's adult inhabit-

\footnotetext{
2 Based on the conducted research, there was no available data to determine if certain functions existed in certain settlements (indicated on the functional orientation map). It is assumed that these functions are non-existent in these settlements, due to their overall low infrastructure, economic and social standard.
} 


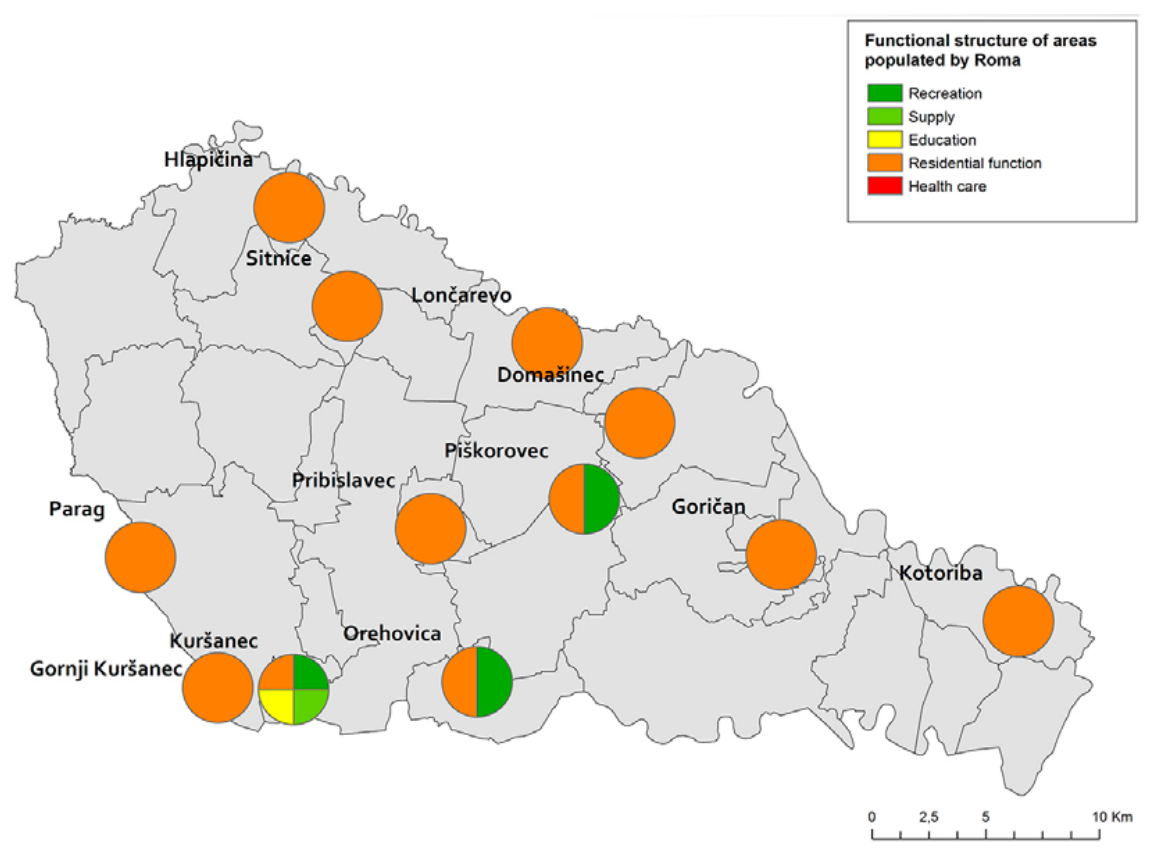

Figure 6. Functional structure of areas populated by Roma

ants claim they speak Croatian fluently, only 1,8\% use Croatian as their mother tongue. On the other hand, $98 \%$ stated that they use Roma language ("bajaški") as mother tongue. The language issues, among other, may be seen as obstacles in interacting with local people and seeking employment.

Kuršanec has a more favourable situation in comparison with other settlements; a football field and children's playground have been built, as well as kinder garden and a grocery store. In the Spatial plan for County Međimurje, Kuršanec is the only Roma settlement with defined recreational, educational and supply functions. The initiative to found a kinder garden and the adjoining family centre - is an example of new projects seeking integration and functional improvement in areas inhabited with Roma.

Of all the previously mentioned functions, it is important to emphasise education, because Roma leadership and local government of Međimurje County have clearly identified education as priority (Strategy of Rural Development in Međimurje County, 2009). Consequently, this function in Roma settlements should be more prioritized. Local governments should be considered as bearers of positive change and the ones responsible for developing new functions in Roma settlements. In order to implement changes, cooperation of the Roma community, education institutions and NGO associations must be realized in order to establish a complete education system and to further contribute to social and economic development (Hrvatić, 2005).

In this context, the problem of functional orientation of areas inhabited by Roma is emphasised. Existing situation in the Roma part of Kuršanec leads to the conclusion that besides socio-cultural habits of Roma people there are no significant functional factors which mobilize the Roma community, as Roma interactions with the majority population occur rarely.

Unemployment and unfavourable education structure leaves these areas in the rural periphery without adequate education, recreation and supply infrastructure. In that way, identification of economic and educational potential as well as diversification of social resources of the Roma community is somewhat difficult. This situation is at the same time the reason and stimulation for further isolation of Roma community.

When researching the quality of communal and social infrastructure in Roma settlements (Rogić, 2005), Roma people identify certain disadvantages. According to the results, the most desirable facilities which are missing in settlements are schools and kinder gardens, then infirmaries and drugstores, grocery stores and sport and recreational facilities.

An encouragement to further improve the existing conditions is the establishment of the Family centre Kuršanec with a complementary kinder garden. UNDP's presence over the last few years has set to motion new changes as well as set path to new actors. The Social agricultural cooperation was established and started with ecological agricultural production. A cooperation which gathers unemployed Roma women between 17 and 35 years of age started with activities as well. Potential to improve the socio-economic situation of Roma is seen in starting Roma family farms and ideas to legalize crafts in which Roma people are traditionally involved, such as collecting and processing secondary raw material. At the same time a sensible question is asked: how to improve the living 
standard of Roma people and stop further segregation through integration and not assimilation.

\section{The state of environment in Roma settlements}

The environment is the total visual manifestation of topography, shapes, created patterns. It is a result of numerous factors and processes which happened or are happening in space. It reflects the former and present relations of people towards the environment (Spatial plan for Međimurje County, 2001). The environment in which Roma people are settled is often characterized by the lack of green areas, a number of waste disposal sites (in the settlements itself), uncared-for common areas and an overall disrupted state of environment.
Degradation and devastation in areas inhabited by Roma starts with unplanned construction of mostly housing units of bad quality. Various, mostly discarded materials are used to build such objects on county, state or municipal land. Existing buildings - if any - or the environment is not taken into consideration (Figure 7 and 8).

The ethnic border between areas inhabited by Roma and the majority population has its own spatial mark. These visual connotations mark a specific cultural landscape of Roma-inhabited areas, whereas they contribute to perceptions of Roma as closed communities (Šlezak, 2010).

By coherent planning of settlements and building areas, the sustainability of these settlements could be

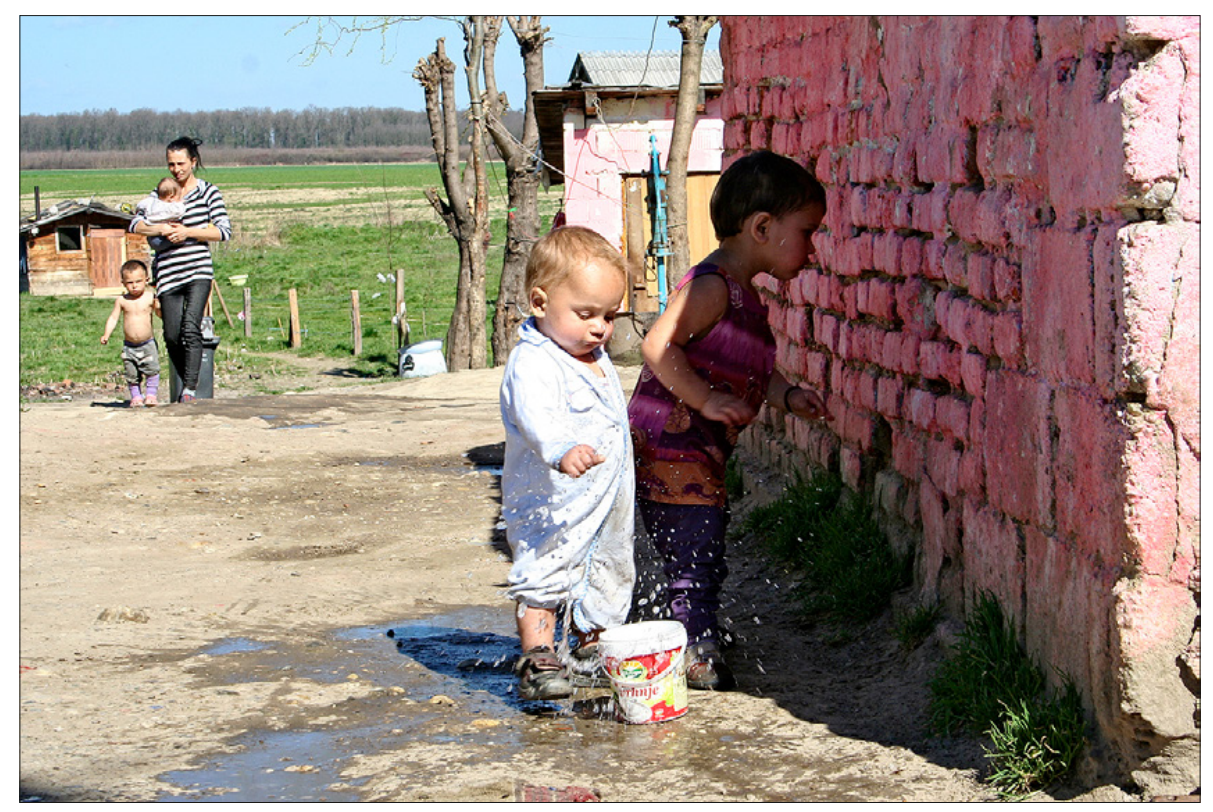

Figure 7. Children in Kuršanec

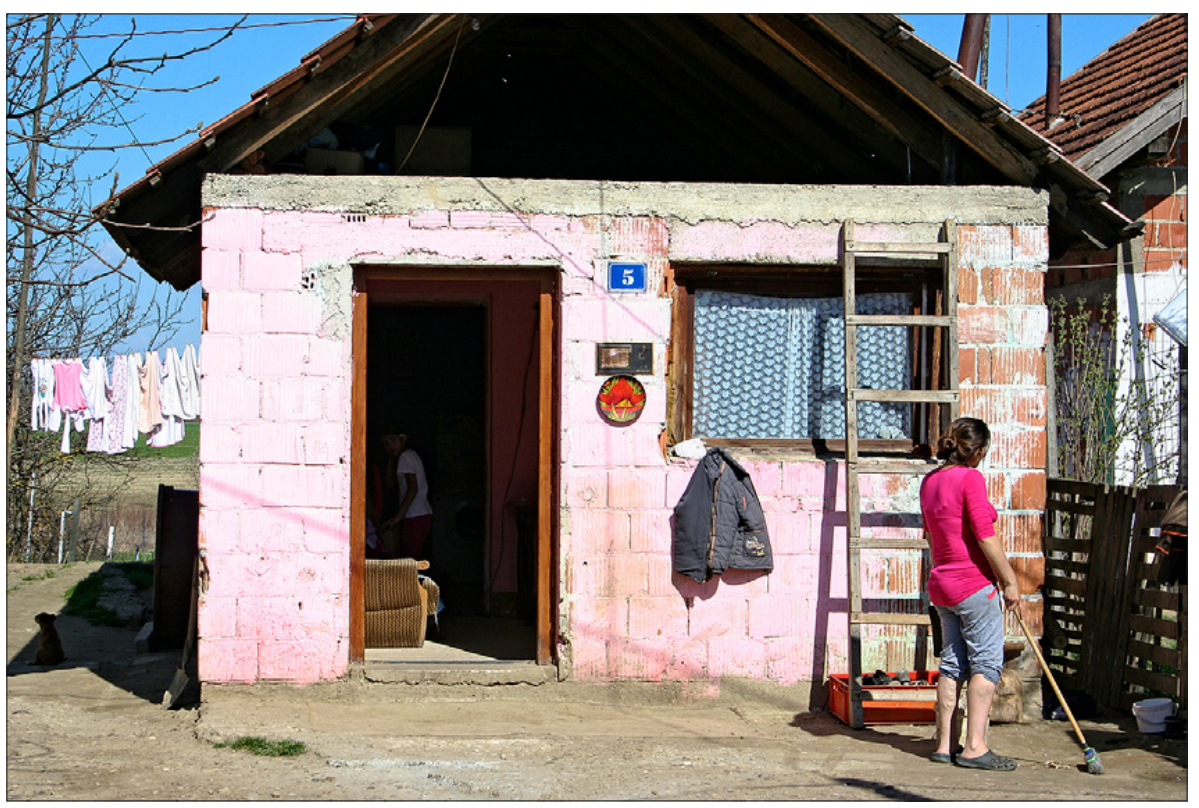

Figure 8. House in Kuršanec 
achieved without further endangering of the environment. It is crucial to utilize space rationally, which must be done by analysing its capacity, needs and the optimal usability of available resources. The objectivity behind this model of use must be based on actual and future population numbers, economic capabilities and specific needs of certain settlements.

\section{Conclusion}

This paper tried to explain some of the characteristics and shortcomings of areas inhabited by Roma in Međimurje County, including infrastructure, economic status and functions of settlements. Kuršanec settlement was selected as a case study, serving as basis for certain conclusions for other areas inhabited by Roma.

Although case study of Kuršanec provides understandings of the Roma situation with its following problems very well, it is recommended to conduct similar analysis for other areas too. The fact is that the level of segregation of Roma is higher in Croatia than in certain neighbouring countries. This tells us about the necessary and emergent need to change our attitudes towards the Roma population. Besides the mentioned, other numerous issues have been indicated during the analysis, which need higher engagement of local and county, but also state officials.

The existing state is characterized by the lack of central functions and the predominance of housing in Roma settlements, which also contributes to segregation. In the so called social ghettos where Roma live, it is necessary to insure access to new facilities, employment and education opportunities in order to decrease the existing social distance. A great importance behind this approach lies in the functional valorisation of Roma informal life, which was in many cases an obstacle to quantification and objective consideration of Roma social resources and, consequentially, to efficient employment policies as well.

From the aforementioned experiences, we believe this kind of approach can recognize the economic potential of Roma people. However, we should have in mind that spatial planning of areas populated by Roma, legalization of existing construction and further construction ventures must be an integral part of this approach, in order to improve the inadequate infrastructural standard of the analysed areas. Further analyses are necessary to adequately comprehend the complex issues of Međimurje's Roma population, as the largest Roma community in one of Croatia's counties. Previous research and papers are more than a decade old so it would be useful to 'revise' them and ascertain if and in which way the situation has changed.
Authors also believe that local governments and Roma representatives should jointly design a developmental plan for areas populated by Roma, since they possess first-hand experience and insight concerning Roma settlements.

\section{References}

Atlas of Roma in Medimurje County, UNDP in Croatia 2013. Available at: www.hr.undp.org (in Croatian)

Action plan for inclusion of Roma in Međimurje county from 2013 to 2015 Čakovec, 2013. Available at: www.medjimurska-zupanija.hr (in Croatian)

First-Dilić, R. 1985. Space stabilization and Roma domestification. Sociologija sela 23, 35-53. (in Croatian)

Hodžić, A. 1985. Living standard of Roma households. Sociologija sela 23, 27-34. (in Croatian)

Hrvatić, N. 2004. Roma in Croatia: From migration to intercultural relations. Migracijske i etničke teme 20(4), 367-385. (in Croatian)

Hrvatić, N. (ed. Štambuk, M.) 2005. Education of Roma in Croatia: assumption for better life quality?. In: Biblioteka Zbornici „Kako žive hrvatski Romi“, Institut društvenih znanosti Ivo Pilar, Zagreb, 177200 pp. (in Croatian)

Report on enforcement of Action plan for implementation of National strategy for Roma inclusion in period 2013-2015, 2014. Available at: www.vlada.gov. hr (in Croatian)

Josipovič, D., Repolusk, P. 2003. Demographic Characteristics of the Romany in Prekmurje. Acta Geographica Slovenica 43(1), 127-147.

Miletić, G.-M. (ed. Štambuk, M.) 2005. Dwelling conditions and dwelling aspiration of Roma). In: Biblioteka Zbornici „Kako žive hrvatski Romi“, Institut društvenih znanosti Ivo Pilar, Zagreb, 159-176 pp. (in Croatian)

National strategy for inclusion of Roma for the period 2013-2020. Vlada Republike Hrvatske, Zagreb, 2012. (in Croatian)

Nejašmić, I. 2005. Demogeogaphy: population in spatial relations and processes). Zagreb, $283 \mathrm{pp}$. (in Croatian)

Pokos, N. (ed. Štambuk, M.) 2005. Demogeographic analysis of Roma on statistical basis. In: Biblioteka Zbornici „Kako žive hrvatski Romi“, Institut društvenih znanosti Ivo Pilar, Zagreb, 35-52. (in Croatian)

Posavec, K. 200o. Sociocultural characteristics of Roma - From exile to integration. Društvena istraživanja 46-47, 229 - 250. (in Croatian)

Spatial plan of Međimurje County 2001. Zavod za prostorno uređenje Međimurske županije. Čakovec. Available at: www.zavod.hr (in Croatian) 
Development strategy of Međimurje County 20112013, 2011. Available at: www.redea.hr (in Croatian)

Rogić, I. (ed. Štambuk, M.) 2005. Some socioecological determinants of Roma settlements. In: Biblioteka Zbornici „Kako žive hrvatski Romi“, Institut društvenih znanosti Ivo Pilar, Zagreb, 53-9o pp. (in Croatian)

Strategy of rural development of Međimurje County 2009. Regionalna razvojna agencija Međimurje, Čakovec. Available at: www.redea.hr (in Croatian)

Šlezak, H. 2009. Spatial segregation of Roma population in Međimurje County. Hrvatski geografski glasnik 71(2), 65-81. (in Croatian)

Šlezak, H. 2010. Demogeografska i sociokulturna obilježja romske populacije u Međimurju (Demogeographic and sociocultural characteristics of Roma population in Međimurje). Magistarski rad, Geografski odsjek Prirodoslovno-matematičkog fakulteta Sveučilišta u Zagrebu.
Šlezak, H., Šakaja, L. 2012. Spatial problems of social distance towards Roma.Hrvatski geografski glasnik 74(1), 91-109. (in Croatian)

Štambuk, M. 2000. Roma in social space of Croatia. Društvena istraživanja 9 (46-47), 197-210. (in Croatian)

Štambuk, M. (ed. Štambuk, M.), 2005. Characteristics of Roma family - households. In: Biblioteka Zbornici „Kako žive hrvatski Romi“" Institut društvenih znanosti Ivo Pilar, Zagreb, 91-11o pp. (in Croatian)

Šućur, Z. 2000. Roma as marginalise group. Društvena istraživanja 9 (46-47), 211-227. (in Croatian)

Zupančić, J. 2007. Roma settlements as special part of settlement system in Slovenia. Dela 27, 215-246. (in Croatian)

Živić, D., Pokos, N. 2005. Selected sociodemographic indicators of Croatia and county development. Revija za sociologiju 36(3-4), 207-224. (in Croatian) 